\title{
Effect of different soil tillage methods on rhizobial nodulation, biyomas and nitrogen content of second crop soybean
}

\author{
Kemal Dogan, Ismail Celik, Mustafa Gok and Ali Coskan* \\ Süleyman Demirel Üniversitesi, Ziraat Fakültesi Toprak Bölümü 32260 Çünür / Isparta, TÜRKIYE. \\ Accepted 15 July, 2011
}

\begin{abstract}
The effects of different soil tillage methods on rhizobial nodulation, biomass yield (root, shoot and nodule) and nitrogen content of soybean as a second crop have been investigated. The experiment was conducted as a field trial in Cukurova Region, Turkey in 2008. Six different tillage methods have been studied in this research. These methods were conventional tillage with residue (CTR), conventional tillage with burnt residue (CTBR), reduced tillage with heavy disking (RTHD), reduced tillage with rotary tiller (RTR), no- tillage with heavy disking (NTHD) and no tillage with direct seeding (NTDS). At the stage of inflorescence, nodulation was investigated in the root, shoot, and nodule samplings by determining the weights of the samples and analyzing them for nitrogen contents. The results have been statically analyzed by using MSTAT-C package programme. According to the results of the study, under the conventional methods in which deep tillage operations are applied to soil, it has been found out that nodule formation and plant nitrogen contents have been negatively affected. The differences among the applications were found to be statistically significant. In general, the best nodulation has been obtained with NTDS and RTHD plots. Moreover, the effects of other tillage methods on some parameters related with rhizobiyal $\mathrm{N}_{2}$-fixation have caused to considerable decrease on the parameters mentined above.
\end{abstract}

Key words: $\mathrm{N}_{2}$-fixation, soil tillage methods, microbial activity.

\section{INTRODUCTION}

Soil tillage methods have complex effects on physical, chemical and biological properties of soil. Because of the changing physical and chemical properties of soil by soil tillage methods, the biological properties of soil may also change. Actually these changes are indirect results of tillage. Changed physical and chemical soil properties by soil tillage methods effect the parameters directly related with soil microbial activities such as organic matter, soil humidity, temperature and ventilation as well as the

\footnotetext{
${ }^{\star}$ Corresponding author. E-mail: acoskan@gmail.com. Tel: +90 2462114632 or +90 5323650848. Fax: +90 2462371693.
}

Abbreviations: CTR, Conventional tillage with residue; CTBR, conventional tillage with burnt residue; RTHD, reduced tillage with heavy disking; RTR, reduced tillage with rotary tiller; NTHD, no- tillage with heavy disking; NTDS, no tillage with direct seeding; CRB, complete randomized block. degrees of interaction between soil mineral and organic matter. As a result of these effects, significant differences can be observed in the population of microbial activities in soil (Wardle, 1995; Lavelle, 2000; Kladivko, 2001; Sagar et al., 2001).

Microbiological properties of soil are affected from any soil problem or productivity and they are accepted as indicator (Sagar et al., 2001; Jinbo et al., 2007). Soil microorganisms are important elements for ecosystem that have active roles on properly functioning of nutrition circulation mechanism. Disconnection or variation at any links of many reaction chains affecting nutrition circulation mechanism can also cause changes the plantmicroorganism interactions. Plant and microorganism interactions in rhizosfer region are very important for plant growth. In the rhizosfer region, rhizobial and mycohorizal activities occur as reciprocal and compulsory interactions (symbiosis) of plant-microorganism (Altieri, 2000; Garcia and Altieri, 2005). One of the important 
activities related to soil qualities is beneficial microorganism activities. The most important of these activities is a root nodule bacterium which provides biological $\mathrm{N}_{2}-$ fixation (Ferreira et al., 2000).

Microorganisms, that are important parts of the nature, are considerably affected by the environmental conditions. These organisms which rapidly reproduce and function in proper environmental conditions, also struggle to continue their functions under poor conditions (Dogan et al., 2007). Although $\mathrm{N}_{2}$ exits in the atmosphere with the rate of $78 \%$, it is not in the useful form for plants and animals. Lots of creatures can't sustain their life activities in the lack of $\mathrm{N}_{2}$, despite its abundance in the atmosphere. Atmospheric $\mathrm{N}_{2}$ has to be converted to available form $\left(\mathrm{NH}_{4}{ }^{+}, \mathrm{NO}_{3}{ }^{-}\right)$for plants. These convertions are carried out mostly by bacteria. Symbiotically $\mathrm{N}_{2}$-fixation rhizobiums and leguminosae plants are very important for annual nitrogen fixation balance and these bacteria add 75 tonne nitrogen in a year all over the world (Lindermann and Glower, 2003; Dogan et al., 2007). In agricultural systems, mean symbiotic nitrogen fixation is $150-200 \mathrm{~kg} / \mathrm{ha}$ and it may reach the value of $300 \mathrm{~kg} / \mathrm{ha}$ when grafting is done suitable rhizobium strain (Gok et al., 1995; Lindermann and Glower, 2003).

As a result of symbiotic $\mathrm{N}_{2}$-fixation, legumes supply nitrogen to the soil not only with their nodules, but also by decomposation of their roots and shoots. Nitrogen might have formed by mixing the seperated dead nodule tissues into the soil. This situation can be accelerated by cutting of the plant's shoots (Werner, 1987; Goormachting et al., 2004).

Soybean plant that is an important food supply for human beings and animals introduced to our country in the 1930s and was cultivated only in the Black Sea Region for many years. With the secondary crop project, conducted in the last 20 years, soybean plant has been cultivated in the irrigated Eagean and Mediterrannean Region soils but today it has been mostly cultivated in Cukurova Region. $80-85 \%$ of Turkey's soybean production is came from Adana and Osmaniye, but in recent years it is reported that soybean production has been decreased (FAO, 2005; Arıoglu, 2007). In this study, the effects of six different tillage systems on rhizobiyal parameters such as nodulation, plant biomass weight and plant nitrogen content of soybean plant were investigated.

\section{MATERIALS AND METHODS}

\section{Study field}

This study has been carried out in the Arık soil series that is located at Çukurova University Agricultural Faculty's application farm. According to the soil taxonomy classification system, the soil varieties are at Vertisol ordo, Haploxerert big group and Typic Haploxerert sub group (Soil Survey Staff, 1999). Arık series soils are plain and nearly plain $0+1 \%$ sloping and deep profiled located on very old alluvial subsoil. They have thick $A$ horizon with $A-C$ horizon arrangement. The color of soil profile is dark brown or brown. In dry summer months, there are wide-deep cracks that have shiny surfaces and make $60^{\circ}$ of angle from vertical and horizontal surfaces in the upper part of the soil. The whole soil profile has clay texture and calcareous, and there is a little calcium wash-outd (Gulez and Senol, 2002).

\section{Climate conditions}

Adana, which is in the Mediterrannean climate zone, has a warm and rainy winter, dry and hot summer climate. According to 30 years of mean climate data, annual mean temperature is $19.1^{\circ} \mathrm{C}$ in Adana. Annual total evaporation rate is $1536 \mathrm{~mm}$ and total raining rate is $670 \mathrm{~mm}$ and $75 \%$ of raining occurs in winter and spring. The average climate data for the last three years (2006-2009) including the data for 2008 when the experiment was conducted is given in Table 1.

\section{Experimental design}

A Complete Randomized Block (CRB) design was implemented within the field with subplots of different tillage methods. There were six different soil tillage methods and each soil tillage method was replicated three times yielding 18 subplots. Each plot was $12 \mathrm{~m}$ in width and $40 \mathrm{~m}$ in length covering an area of $480 \mathrm{~m}^{2}$.

\section{Soil tillage methods}

Six different soil tillage methods have been applied in this study. These methods were conventional tillage with residue (CTR), conventional tillage with burnt residue (CTBR), reduced tillage with heavy disking (RTHD), reduced tillage with rotary tiller (RTR), notillage with heavy disking (NTHD) and no tillage with direct seeding (NTDS). These methods were replicated three times. As secondary crop, soybean was planted to the plots after winter wheat. The details of the tillage operations applied for winter wheat and soybean are given in Table 2 .

\section{Cultivation, maintenance and harvest processes}

Soil tillage applications, mentioned in previous section and wheat cultivation have been performed in 17.11.2007 for the 2007-2008 production periods. In the years of 2007-2008, $161 \mathrm{~kg} \mathrm{~N} \mathrm{ha}^{-1}$ nitrogen and $40 \mathrm{~kg} \mathrm{P}_{2} \mathrm{O}_{5} \mathrm{ha}^{-1}$ phosphours have been applied as preplant and top-dress fertilization. No-irrigation has been applied in the wheat growing season and herbicide has been applied to kill the weeds and wild oats before spiking. Wheat was harvested 25.05.2008. The next application was to cultivate soybean by using six different soil tillage methods in 30.05 .2008 as a secondary crop according to the objectives of the research.

Arisoy variety has been used as a secondary soybean. Before the cultivation Bradyjaponicum bacteria inoculation $(400 \mathrm{~g} / 100 \mathrm{~kg}$ seed) has been applied to the soybean seeds. Soybean seeds, inoculated with bacteria, were planted in $70 \mathrm{~cm}$ of row width and $6 \mathrm{~cm}$ of on-row spacing by direct seeding machice. While cultivating soybean, $0.4 \mathrm{~kg} \mathrm{~N} \mathrm{da}^{-1}$ nitrogen (encouragement $\mathrm{N}$ ) and $0.4 \mathrm{~kg}$ $\mathrm{P}_{2} \mathrm{O}_{5} \mathrm{da}^{-1}$ phosporus have been applied according to soil test results. After germination, the plots were irrigated 8 times with the 12-13 day- intervals by sprinkler irrigation method. Since climate conditions of the study area was appropriate for development of deseases and pests, herbicide application was made three times for successful weed and pest management. By analyzing root and leaf samples, nodule development was investigated, biomass yield and nitrogen contents were also determined at the blooming stage. 
Table 1. 2006-2009 years of climate data that belong to centre of Adana (Anonymous, 2009).

\begin{tabular}{|c|c|c|c|c|c|c|c|c|c|c|c|c|c|}
\hline \multirow{2}{*}{ Climate parameters } & \multicolumn{13}{|c|}{ Months } \\
\hline & $\mathrm{I}$ & II & III & IV & $\mathbf{V}$ & VI & VII & VIII & IX & $x$ & $\mathbf{X I}$ & XII & Average \\
\hline Max. & 11.1 & 12.3 & 16.5 & 19.5 & 24.5 & 27.3 & 29.7 & 30.7 & 26.9 & 23.4 & 17.3 & 12.7 & 21 \\
\hline Min. Temp. $\left({ }^{\circ} \mathrm{C}\right)$ & 6.8 & 8.0 & 10.2 & 14.2 & 21.1 & 25.5 & 27.9 & 26.6 & 24.4 & 19.6 & 13.2 & 8.8 & 17.2 \\
\hline Average Temp. $\left({ }^{\circ} \mathrm{C}\right)$ & 9.1 & 10.1 & 13.4 & 17.4 & 22.3 & 26.3 & 28.8 & 29 & 26.1 & 21.6 & 15.4 & 10.7 & 19.2 \\
\hline Average Mosit. (\%) & 63.9 & 71.6 & 70.8 & 67.8 & 68.6 & 71.8 & 75.7 & 76.4 & 68.2 & 66.3 & 67.2 & 64.6 & 69.6 \\
\hline Total evaporation (mm) & 53.5 & 50.4 & 88.4 & 147.8 & 183.7 & 238 & 253.2 & 235.6 & 178 & 126.1 & 73 & 52.7 & 1674.7 \\
\hline Ave. Total rains (mm) & 62.1 & 111 & 70.8 & 44.4 & 24.9 & 11.4 & 14.2 & 3.2 & 18.2 & 68.7 & 73.3 & 61.2 & 563.2 \\
\hline
\end{tabular}

Table 2. Soil tillage methods in the major and secondary crop production.

\begin{tabular}{|c|c|c|}
\hline Soil tillage methods & Soil tillage for winter wheat cultivation & Soi tillage for second crop soybean plant \\
\hline $\begin{array}{l}\text { Conventional tillage with } \\
\text { residue (CTR) }\end{array}$ & $\begin{array}{l}\text { - } \text { Chopping the residues } \\
\text { - Plowing }(30-33 \mathrm{~cm}) \\
\text { - Disk horrow }(13-15 \mathrm{~cm}) \text { (2 times) } \\
\text { - Packing (2 times) } \\
\text { - Wheat planting with a universal planter }(4 \mathrm{~cm})\end{array}$ & $\begin{array}{l}\text { - } \text { Chopping the residues } \\
\text { - Heavy disk horrow }(18-20 \mathrm{~cm}) \\
\text { - } \text { Disk horrow }(2 \text { times })(13-15 \mathrm{~cm}) \\
\text { - Packing }(2 \text { times }) \\
\text { - Soybean planting with Pneumatic- } \\
\text { precision seeding machine }(8 \mathrm{~cm})\end{array}$ \\
\hline $\begin{array}{l}\text { Conventional tillage with } \\
\text { burnt residue (CTBR) }\end{array}$ & $\begin{array}{l}\text { - Burning the residues } \\
\text { - Plowing }(30-33 \mathrm{~cm}) \\
\text { - Disk horrow }(13-15 \mathrm{~cm})(2 \text { times }) \\
\text { - Packing (2 times) } \\
\text { - Wheat planting with a universal planter }(4 \mathrm{~cm})\end{array}$ & $\begin{array}{l}\text { - Burning the residues } \\
\text { - Chiseling }(35-38 \mathrm{~cm}) \\
\text { - Disk horrow }(13-15 \mathrm{~cm})(2 \text { times }) \\
\text { - Packing (2 times) } \\
\text { - Soybean planting with Pneumatic- } \\
\text { precision seeding machine }(8 \mathrm{~cm})\end{array}$ \\
\hline $\begin{array}{l}\text { Reduced tillage with } \\
\text { heavy disking (RTHD) }\end{array}$ & $\begin{array}{l}\text { - Chopping the residues } \\
\text { - Heavy disking }(18-20 \mathrm{~cm})(2 \text { times }) \\
\text { - Packing }(2 \text { times }) \\
\text { - Wheat planting with a universal planter }(4 \mathrm{~cm})\end{array}$ & $\begin{array}{l}\text { - } \text { Chopping the residues } \\
\text { - Rotary tilling }(13-15 \mathrm{~cm}) \\
\text { - Packing (2 times) } \\
\text { - Pneumatic-precision seeding machine ( } 8 \\
\text { cm) }\end{array}$ \\
\hline $\begin{array}{l}\text { Reduced tillage with } \\
\text { rotary tiller (RTR) }\end{array}$ & $\begin{array}{l}\text { - Chopping the residues } \\
\text { - Rotary tilling }(13-15 \mathrm{~cm}) \\
\text { - Packing }(2 \text { times }) \\
\text { - Wheat planting with a universal planter }(4 \mathrm{~cm})\end{array}$ & $\begin{array}{l}\text { - Chopping the residues } \\
\text { - Rotary tilling }(13-15 \mathrm{~cm}) \\
\text { - Packing (2 times) } \\
\text { - Soybean planting with Pneumatic- } \\
\text { precision seeding machine }(8 \mathrm{~cm})\end{array}$ \\
\hline $\begin{array}{l}\text { No-Tillage with Heavy } \\
\text { Disking (NTHD) }\end{array}$ & $\begin{array}{l}\text { - } \text { Chopping the residues } \\
\text { - Heavy disking }(18-20 \mathrm{~cm}) \\
\text { - Doting (2 times) } \\
\text { - Wheat planting with a universal planter }(4 \mathrm{~cm})\end{array}$ & $\begin{array}{l}\text { - Chopping the residues } \\
\text { - Herbicide application } \\
\text { - Soybean planting with Pneumatic- } \\
\text { precision seeding machine }(8 \mathrm{~cm})\end{array}$ \\
\hline $\begin{array}{l}\text { No-Tillage with Direct } \\
\text { Seeding (NTDS) }\end{array}$ & $\begin{array}{l}\text { - Chopping the residues } \\
\text { - Herbicide application } \\
\text { - Wheat seeding with direct seeder }(4 \mathrm{~cm})\end{array}$ & $\begin{array}{l}\text { - Chopping the residues } \\
\text { - Herbicide application } \\
\text { - Soybean planting with Pneumatic- } \\
\text { precision seeding machine }(8 \mathrm{~cm})\end{array}$ \\
\hline
\end{tabular}


Table 3. Basic soil properties of the study field $(0-30 \mathrm{~cm})$.

\begin{tabular}{ccccccccccc}
\hline $\begin{array}{c}\text { pH } \\
\left(1: 2.5 \mathrm{H}_{2} \mathrm{O}\right)\end{array}$ & $\begin{array}{c}\text { Salt } \\
\left.(\mathbf{m m h o s c m})^{1}\right)\end{array}$ & $\begin{array}{c}\mathrm{CaCO}_{3} \\
(\%)\end{array}$ & $\begin{array}{c}\text { Org. Mat. } \\
\%\end{array}$ & $\begin{array}{c}\mathbf{P}_{2} \mathrm{O}_{5} \\
\mathbf{k g . h a}^{-1}\end{array}$ & $\begin{array}{c}\mathrm{Nmin}_{\mathbf{k g}^{-1}} \\
\mathbf{k g h}^{-1}\end{array}$ & $\begin{array}{c}\mathbf{N t} \\
(\%)\end{array}$ & $\begin{array}{c}\text { Sand } \\
(\%)\end{array}$ & $\begin{array}{c}\text { Silt } \\
(\%)\end{array}$ & $\begin{array}{c}\text { Clay } \\
(\%)\end{array}$ & Texture \\
\hline 7.82 & 0.15 & 24.39 & 1.27 & 43.5 & 20.3 & 0.072 & 17.5 & 33.2 & 49.3 & Clay \\
\hline
\end{tabular}

Table 4. Variance analysis results $(P<0,05)$.

\begin{tabular}{lccccccc}
\hline $\begin{array}{l}\text { Variance } \\
\text { analysis }\end{array}$ & $\begin{array}{c}\text { Root weight } \\
\text { (kg/ha) }\end{array}$ & $\begin{array}{c}\text { Shoot weight } \\
\text { (kg/ha) }\end{array}$ & $\begin{array}{c}\text { Nodule number } \\
\text { (no/plant) }\end{array}$ & $\begin{array}{c}\text { Nodule weight } \\
\text { (kg/ha) }\end{array}$ & $\begin{array}{c}\text { Average nodule } \\
\text { weight (mg//Nodule) }\end{array}$ & $\begin{array}{c}\text { Root N } \\
\%\end{array}$ & $\begin{array}{c}\text { Shoot N } \\
\%\end{array}$ \\
\hline Mean square & 49438.652 & 6432332.430 & 266.503 & 824.843 & 2.081 & 0.011 & 0.047 \\
LSD values & 211.8 & 2416 & 15.550 & 27.28 & 1.374 & 0.999 & 0.207 \\
\hline
\end{tabular}

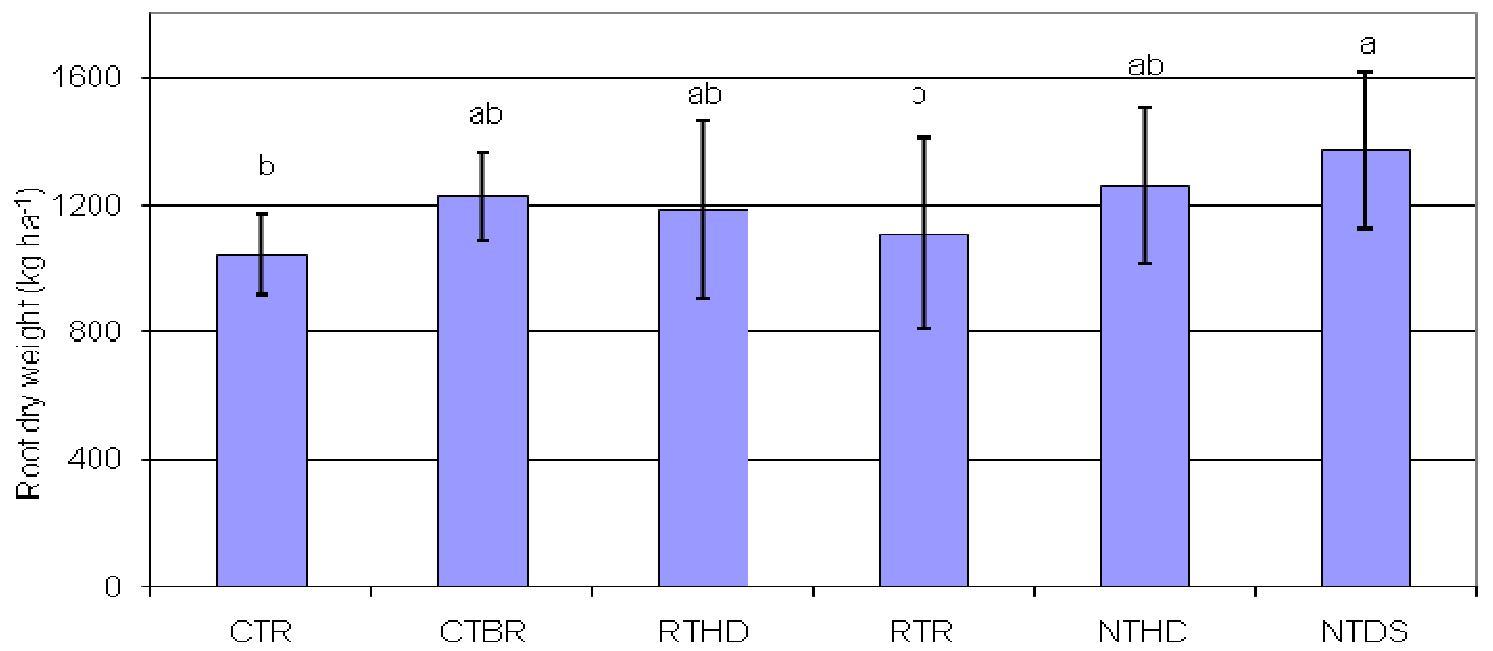

Figure 1. The effects of different soil tillage methods on secondary crop soybean in terms of dry root weight.

\section{Soil analyzes before the experiments}

Soil samples, taken from research area, have been applied to texture analyze with hydrometer method according to Bouyoucos (1951), lime has been obtained with Scheibler calcimeter (Caglar, 1949), 1:2.5 mixture of soil-water of total salt, has been determined with electrical conductivity method, and soil reaction has been determined in the same solution with Beckman pH meter (U.S. Salinity Labaratory Staff, 1954). Basic soil properties of the research field have been given in Table 3.

\section{Plant analysis}

The dry weights of biomass $(\mathrm{kg} / \mathrm{ha})$, number of nodules (number/plant), nodule weight $(\mathrm{kg} / \mathrm{ha})$, average nodule weight (mg/nodule), and nitrogen concentrations (\%) of root and shoot were determined from the samples taken at the blooming stage of soybean.

\section{Statistical analysis}

Variance analysis has been carried out on the data by using
MSTAT-C package programme (Crop and Soil Sciences Department, Michigan State University, Version 1.2). The data was classified by using Duncan Test (Bek, 1983). A Complete Randomized Design (CRD) was implemented within the field.

\section{RESULTS}

This study was conducted to investigate the effects of different soil tillage methods on nitrogen fixation parameters to the secondary crop soybean. The variance analysis results are given in Table 4.

\section{Biomass weights of root and shoot}

According to the Figure 1, in which the effects of different soil tillage methods to the dry root weight are shown, the highest value $(\mathrm{kg} / \mathrm{ha})$ was detected in NTDS as 1372 , whereas the lowest was 1044, obtained with stubble CTR. These statistical differencies have been found 


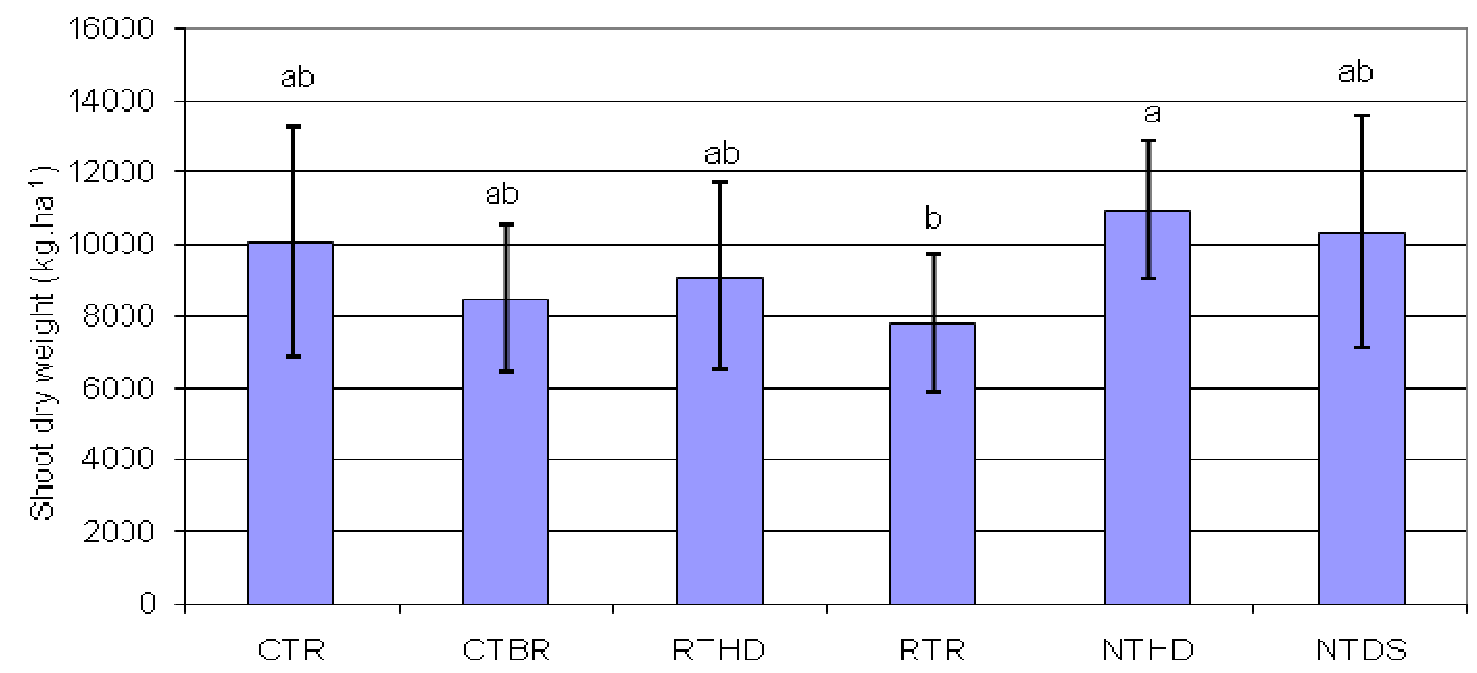

Figure 2. The effects of the different soil tillage methods on the secondary crop soybean plants shoot weight.

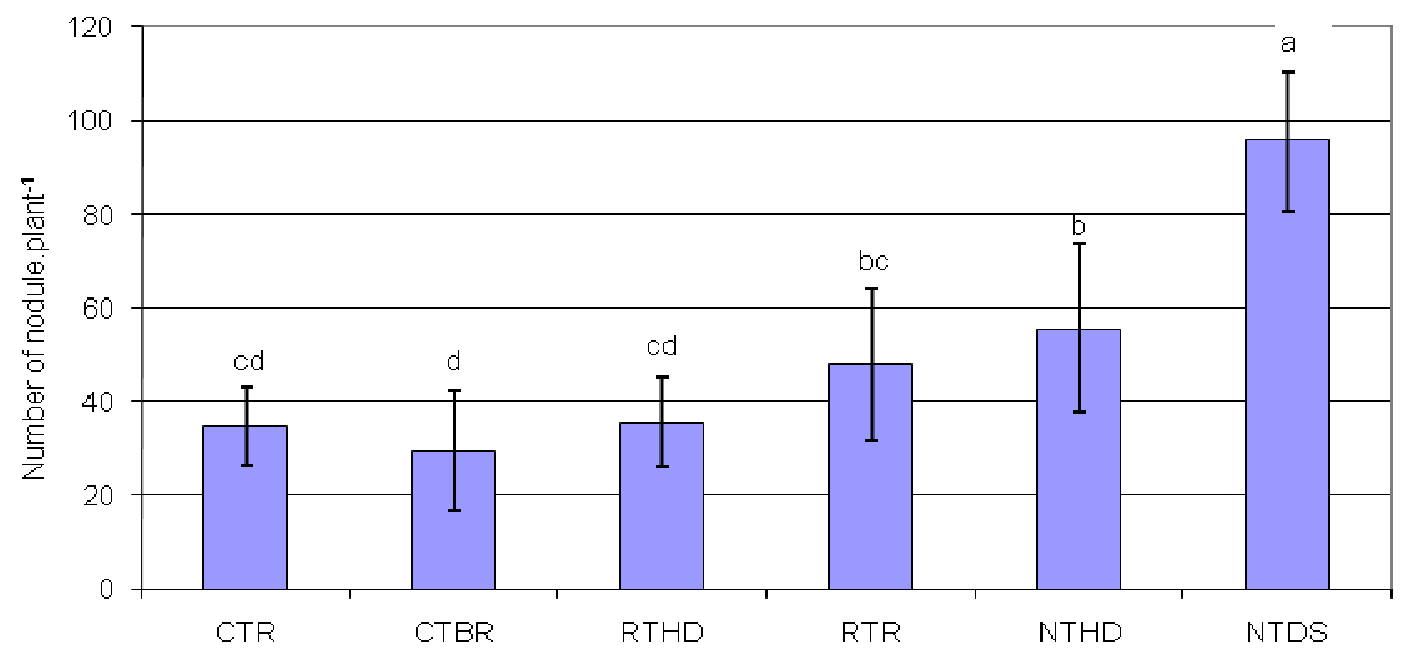

Figure 3. The effects of different soil tillage methods on secondary crop soybean plant.

significant. The similar results were obtained with the other tillage methods.

RTHD gave statistically higher dry root weight (10945 $\mathrm{kg} / \mathrm{ha}$ ) when compared with the other applications (Figure $2)$. The lowest dry root weight value (7796 kg/ha) was obtained in plots of RTR. Results of plant biomass weight have been affected positively and gave higher values in NTHD and NTDS tillage methods. Similar studies showed that the soil tillage methods not only affect the soil biological properties positively but also affects the plant growth positively (Sidiras et al., 1982; Ferreira et al., 2000).

\section{Nodulation}

The effects of the tillage methods on the number of nodules can be seen in the Figure 3 . The number of nodules which is the most important parameter of nitrogen fixation is significantly affected by the soil tillage methods. According to the mean values, the highest nodule number was 96 per plant in NTDS plots. The nodule numbers with the other applications were changed between 30 number/plant (CTBR) and 56 number/plant (NTHD). The low rates of nodules on the plots with burnt residue (CTBR) may have been explained by the destruction of Rhizobium bacterias in dormant form. As it is known, when the residue is burnt the higher temperatures in soil surfaces adversely affect the soil organisms, the amount of organic matter, the availability of soil nutrients, and consequently the soil fertility.

According to the values shown in Figure 3 , in the reduced tillage systems (RTHD and RTR) the nodule 


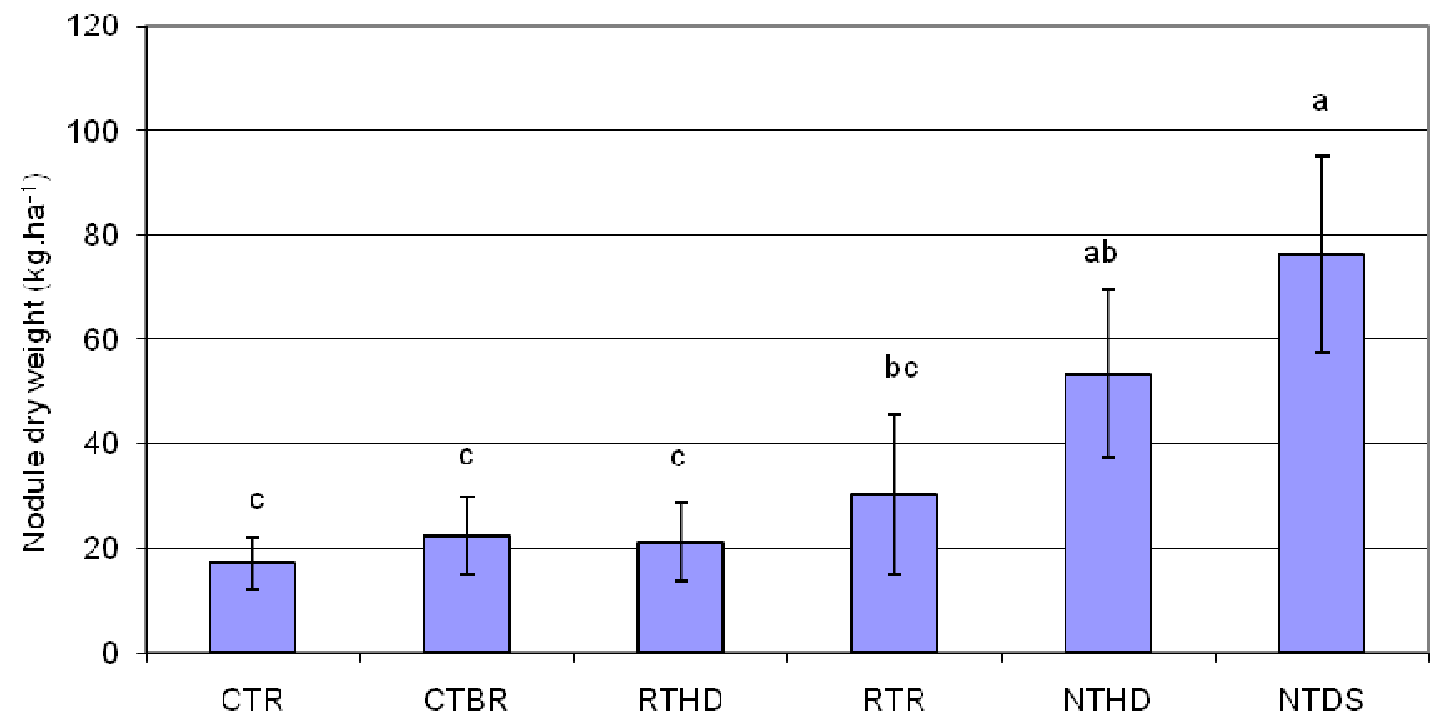

Figure 4. The effects of different soil tillage methods on mean nodule weight.

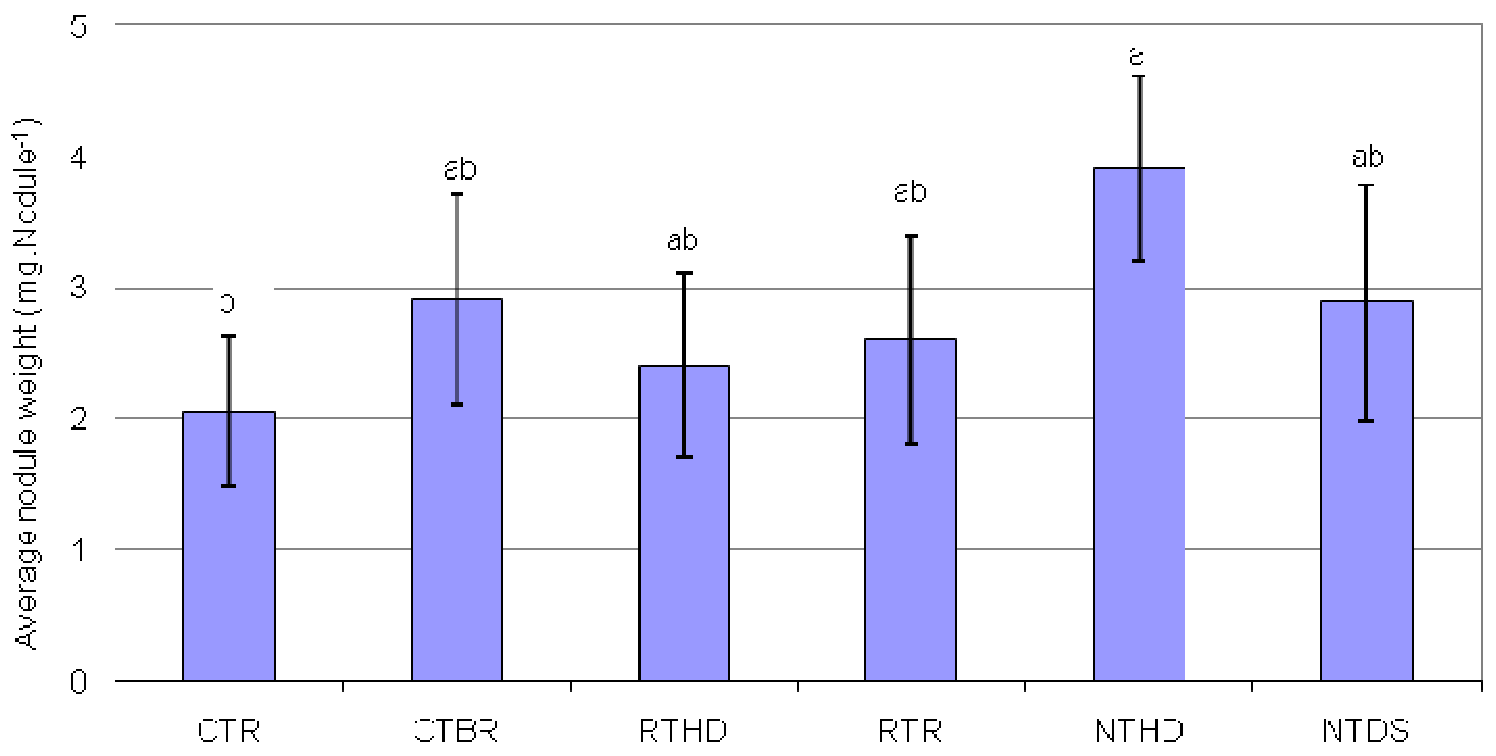

Figure 5. The effects of different soil tillage methods on soybean plant by means of mean nodule weight.

numbers were increased compared to the conventional tillage systems. As the number of tillage operation and the tillage depth are increased, the nodule numbers are decreased.

Many similar studies conducted in different conditions and locations were resulted that no-tillage systems had positive effects on soil microbial activities (Olivares, 2004; Urzua, 2005; Hassen et al., 2007).

Figure 4 shows the dry weights of nodules for different tillage systems. It can be seen that tillage systems have significant effects on the nodule weights. The highest dry nodule values have been observed in the NTDS plots with $0.763 \mathrm{~kg} / \mathrm{ha}$ whereas, the lowest values have been observed in CTBR plots and NTHD plots with 17.06$22.40-21.07 \mathrm{~kg} / \mathrm{ha}$, respectivly.

The dry weights of nodules have been investigated and it was determined that there are some differences among the soil tillage methods (Figure 5). The highest mean nodule weight has been measured on NTHD plots with the rate of $3.91 \mathrm{mg} /$ nodule, whereas the lowest value has been measured on CTR plots with the rate of 2.06 $\mathrm{mg} /$ nodule. Other applications (CTBR, RTHD, RTR and NTDS) gave similar results and the mean nodule weights for these applications are 2.91, 2.41, 2.61 and 2.89 


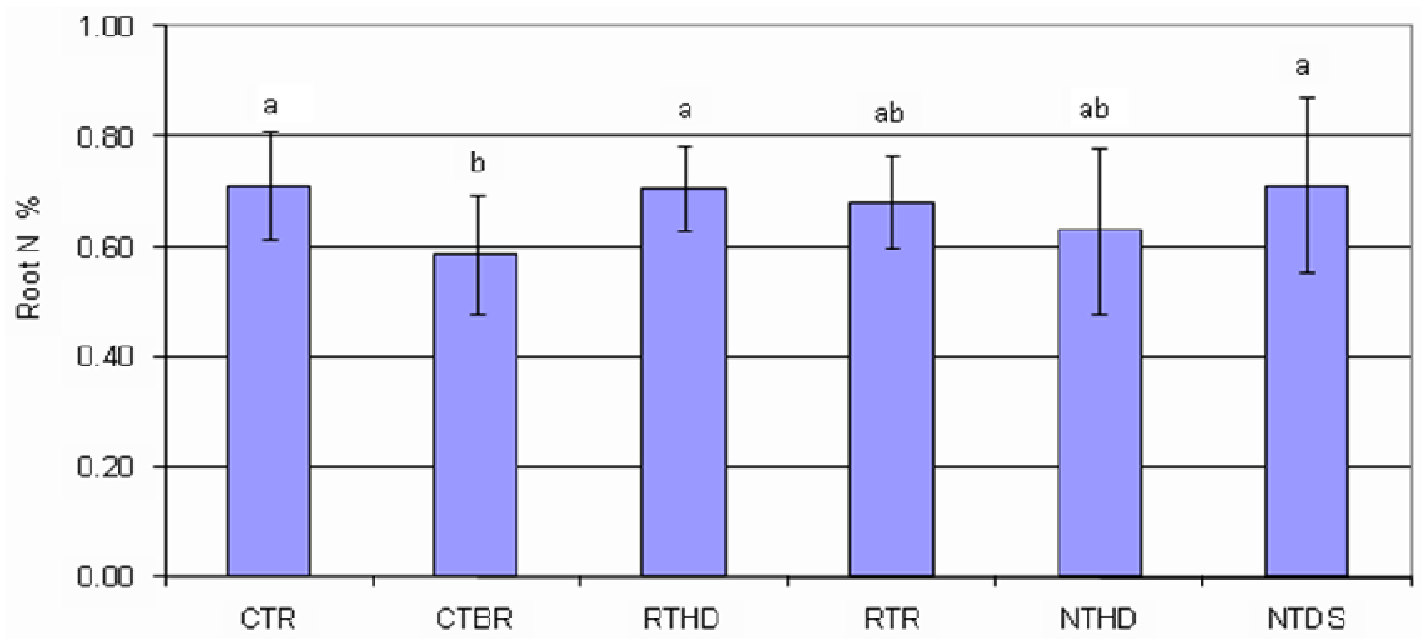

Figure 6. The effects of different soil tillage methods on the concentrations of root $\mathrm{N}$.

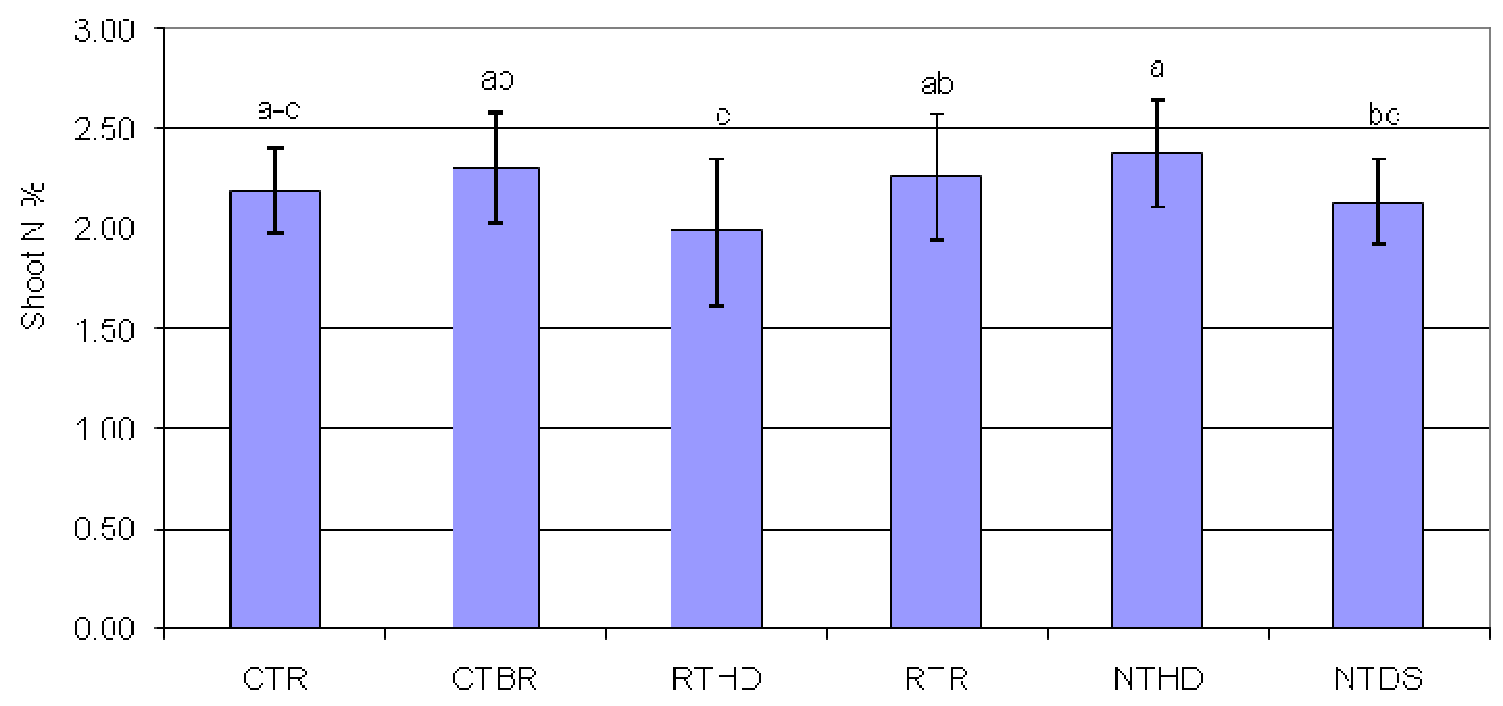

Figure 7. The effects of different soil tillage methods on the concentrations of up-root N.

$\mathrm{mg} /$ nodule,respectively.

\section{Root and shoot $\mathrm{N}$ content (\%)}

According to the results shown in Figure 6, which represent only root (without nodule) nitrogen concentration, significant difference have been come out among the applications and while CTR, RTHD and NTDS applications have the highest values, the lowest values have been observed in CTBR plots as $0.59 \%$. RTR and NTHD plots have nitrogen concentration values of 0.68 and $0.63 \%$, respectively. The most important finding is, if the wheat stubble is burned before before soybean, the root nitrogen concentration is decreased. This can be explained by the destruction of rhizobial activities with the burning process. Moreover, destruction of organic substances in the soil, and benefits of food elements may be another factor. Different soil tillage applications have significant effects on up-root nitrogen concentrations (\%) and the highest value of $2.38 \%$, have been observed on NTHD plots. The lowest value of $1.98 \%$ has been measured on RTHD plots (Figure 7).

\section{DISCUSSION}

In this study, the effects of six different soil tillage methods on some parameters related with nitrogen 
fixation have been investigated. Every effect that soil is subjected has positive or negative reactions. Soil is alive and dynamic system whose physical, chemical, and biological properties are constantly in interaction with each other and changes in any properties effetcs other properties. By soil tillage, the chemical and biological characteristics of soil are also affected due to physical manipulation that the soil subjected. Such organisms like rhizobium and mycorrhiza providing many significat benefits together with the plants and their activities are considerably affected by the changes in surrounding area (Urzua, 2005; Hassen et al., 2007; Dogan et al., 2007).

According to the findings of the research in the NTDS plots, root weights (6.9 g/plant), number of nodules (96 number/plant), weight of nodules ( $0.318 \mathrm{~g} /$ plant) and root nitrogen content $(0.7 \% 1)$ are found to be statistically higher than with the other tillage applications. In the Reduced tillage with rotary tiller (RTR) plots, the values of up-root dry weight $(51.3 \mathrm{~g} /$ plant), mean nodule weight (3.91 $\mathrm{mg} /$ nodule), root $\mathrm{N}$ content $(2.38 \%)$, are found higher on the lands than in NTDS plots.

Among the applications, in the plots of Reduced Tillage (RTHD and RTR) rhizobial nitrogen fixativy parameters have been found considerably higher compared with the other applications. However, some soil tillage methods used in this study negativelyaffected some soil parameters. For the RTR plots the dry root weight (4.8 $\mathrm{g} /$ plant), up-root weight ( $35.7 \mathrm{~g} / \mathrm{plant}$ ) and root $\mathrm{N}$ content $(0.68 \%)$ values and for the Conventional Tillage with Burnt Residue (CTBR) plots, number of nodules and weight of nodule values were found to be lower than in the other tillage applications. The values of dry nodule weights, like in CTBR were low in the plots of CTR and RTHD with the values 0.071 and $0.088 \mathrm{~g} / \mathrm{plant}$, respectively. Besides, the lowest mean nodule weights (2.06 mg/nodule) have been observed in CTR plots and the lowest up root $\mathrm{N}$ content (1.98\%) have been observed in RTHD plots.

The results of the study have been showed that, parameters of nitrogen rhizobial fixation has been affected negatively by the conventional tillage methods in which 3-5 tillage operations are applied and soil is disturbed. There were differences among the tillage methods and these differences were found to be statistically significant. In general, the best results related with rhizobial activity have been obtained with NTDS and NTHD. However, other soil tillage methods decreased the nitrogen fixation. Similar studies have also showed that zero and reduced soil tillage methods have increased the soil microbial activity and population (Alvarez et al., 1995; Gassen and Gassen 1996; Ferreria, 2000).

Generally, soil microbial activity is affected negatively by soil tillage. (Hussain et al., 1999; Kladivko, 2001; Sagar et al., 2001; Jinbo et al., 2007; Hernandez and Hernandez, 2002). Rhizobial activity can also be affected negatively by soil tillage (Ferriera et al., 2000; Urzua, 2005; Hassen et al., 2007). Soil organic matter decreased by soil tillage operations is also important for the vital activities of soil microorganisms. The decrease of organic matter in the soil can also cause decreases in soil microbial activity (Elliot el al., 1984; Hussain et al., 1999; Sagar et al., 2001). As it can be seen in the similar studies, the effects of soil tillage methods may differ depending on climate, regional, and enviromental factors. These factors must be taken into consideration before applying tillage methods. Otherwise, biological activity, fertility and sustainability of soil will be destroyed.

This study showed that for this region and for secondary crop soybean, nodulation is affected positively with RTHD and NTDS methods. Thus, by considering the nodulation is an important parameter of Rhizobial nitrogen fixation, similar studies must be conducted in different soil types. It is recommended that RTHD and NTDS methods can be used for secondary product soybean plant instead of CTR and CTBR.

\section{REFERENCES}

Altieri MA (2000). The ecological impacts of transgenic crops on agroecosystem health. Ecosyst. Health, 6:13-23.

Alvarez R, Dõaz RA, Barbero N, Santanatoglia OJ, Blotta L (1995). Soil organic carbon, microbial biomass and $\mathrm{CO} 2-\mathrm{C}$ pro-duction from three tillage systems. Soil Tillage Res., 33:17-28.

Arıoglu H (2007). Yag Bitkileri Yetiştirme ve Islahi. C.U. Ziraat Fak. Genel Yayın No: 220. Ders Kitapları Yayın No: A-70. ADANA.

Bek Y (1983). Arastırma ve Deneme Metodlari. C.U. Ziraat Fakültesi Ders Notu Yay. No: 92. Adana.

Bouyoucos GJ (1951). A Recalibration of the Hydrometer Method for Making Mechanical Analysis of Soils. Agron. J., 43:434-438.

Caglar KO (1949). Toprak Bilgisi. A.U. Zir. Fak. Yayınları:10, s 230.

Dogan K, Gok M, Coskan A (2007). Bakteriyel Asilama ile Demir Uygulamalarının 2. Urun Yerfistigi Bitkisinde Nodulasyon ve Azot Fiksasyonuna Ekisi. Cukurova Universitesi, Ziraat Fakültesi Dergisi., 22(3):43-52.

Elliot ET, Coleman DC, Ingham RE, Trofymow JA (1984). Carbon and energy low through microflora and microfauna in the soil subsystem of terrestrial ecosystems. In: Klug, M.J., Reddy, C.A. (Eds.), Current Perspectives in Microbial Ecology. American Society of Microbiology, Washington, DC.

FAO (2005). www. http://www.fao.org/

Ferreira MC, Andrade DS, Maria L, Chueire O, Takemura SM, Hungria $M$ (2000). Tillage method and crop rotation efects on the population sizes and diversity of bradyrhizobia nodulating soybean. Soil Biol. Biochem., 32:627-637.

Garcia AG, Altieri MA (2005). Transgenic Crops: Implications for Biodiversity and Sustainable Agriculture. Bull. Sci. Technol. Soc., Vol. 25(4):335-353.

Gassen D, Gassen F (1996). Plantio Direto, o Caminho do Futuro. Aldeia do Sul, Passo Fundo, Brazil (207 pp.).

Gok M, Anlarsal AE, Ulger AC, Yücel C, Onac I (1995). Bazi baklagil yesil gubre bitkilerinde N2-fiksasyonu ve Biyomas verimi. Ilhan Akalan Toprak ve Cevre Sempozyumu Cilt, Il:207-216.

Goormachting S, Capoen W, Holsters M (2004). Rhizobium infection: lessons from the versatile nodulation behaviour of water-tolerant legumes. Trends Plant Sci., 9: 518-522.

Gulez M, Senol S (2002). Cukurova Universitesi Ziraat Fakultesi Toprak Bolumu Deneme Alaninin Detayli Toprak Etud ve Haritalamasi. C.U.Z.F. Dergisi, 17(3):103-110. Adana.

Hassen AA, Xu J, Yang J (2007). Growth conditions of associative nitrogen-fixing bacteria enterobacte cloace in rice plants. Agric. J., 2 (6):672-675.

Hussain I, Olson KR, Ebelhar SA (1999). Long-Term Tillage Effects on Soil Chemical Properties and Organic Matter Fractions. Soil Sci. Soc. Am. J., 63:1335-1341.

Jinbo Z, Changchun S, Wenyan Y (2007). Effects of cultivation on soil 
microbiological properties in a freshwater marsh soil in Northeast China. Soil Tillage Res., 93:231-235.

Kladivko JK (2001). Tillage systems and soil ecology. Soil Tillage Res., 93:61-76.

Lavelle P (2000). Ecological challenges for soil science. Soil Sci., 1651:73-86.

Lindermann WC, Glover CR (2003). Nitrogen Fixation by Legumes. Cooperative Extension Service. College of Agriculture and Home Economiccs. New Mexico State Uni.Electronic distribution.

Olivares J (2004). Fijación Biológica de Nitrógeno. www.eez.csic.es/ Olivares/ciencia/fijacion/(accessed 11 May 2005). Estación Experimental del Zaidín, Granada, España. 10 pp.

Sagar S, Yeates GW, Shepherd TG (2001). Cultivation effects on soil biological properties, microfauna and organic matter dynamics in Eutric Gleysol and Gleyic Luvisol soils in New Zealand. Soil Tillage Res., 58:55-68.
Sidiras N, Henklain JC, Derpsch R (1982). Comparison of three different tillage systems with respect to aggregate stability, the soil and water conservation and the yields of soybean and wheat on an oxisol. J. Agron. Crop Sci., 151:137-148.

U.S. Salinity Laboratory Staff (1954). Diagnosis and Improvement of Saline and Alkaline Soils, USDA No: 6.

Wardle DA (1995). Impacts of disturbanceon detritus food webs on agro-ecosystems of contrasting tillage and weed management practices. In begon M., Fitter, A.H.,(Eds), Advances in ecological Research Vol. 26. Academic Press. New york p. 105-185.

Werner D (1987). Pflanzliche und Mikrobielle Symbiosen. Georg Thieme Verlag Stuttgart. New York. 